\title{
INFLUENCE OF BARIUM OXIDE ADDITIONS ON PORTLAND CLINKER
}

\author{
"ANEŽKA ZEZULOVÁ****, THEODOR STANĚK**, TOMÁŠ OPRAVIL* \\ *Faculty of Chemistry, Brno University of Technology, Purkyňova 118, Brno 612 00, Czech Republic \\ **Research Institute for Building Materials, Hněvkovského 30/65, Brno 617 00, Czech Republic \\ "E-mail: Anezka.Zezulova@vut.cz
}

Submitted March 31, 2016; accepted October 15, 2016

\begin{abstract}
Keywords: Alite, Belite, Barium content determination, Portland cement, Raw meal
Nowadays, nuclear power plants are widespread around the world and research is of great interest. Together with nuclear research, shielding of different types of radiation is an important current topic of research aiming at their safety. Portland cement has been an elementary building material for centuries. Since barium is very efficient in shielding different types of radiation, it can be assumed that the radiation shielding capability of cement can be improved by incorporation of barium. This work deals with the influence of barium oxide, added in the form of barium carbonate and sulphate, on the formation and properties of Portland clinker. The structure of burnt clinkers and the ratio of clinker phases were studied by polarizing microscopy and by X-ray diffraction. With increasing barium content, the alite-belite ratio decreases and the content of free lime gradually increases. Moreover, sulphates induce the growth of alite crystals. The ability of barium to be a part of the clinker minerals was observed by scanning electron microscopy. Belite and clinker melt contain the highest amount of barium, but aggregates of barium oxide are formed in the clinker melt. Furthermore, the rate of alite crystallization was studied under isothermal conditions.
\end{abstract}

\section{INTRODUCTION}

Portland cement has been widely used for centuries as an elementary binding material, and it is very often modified in order to obtain special properties depending on the application. One of the best-known is cement for roads which has a limited $\mathrm{C}_{3} \mathrm{~A}$ content in the clinker (under $8 \mathrm{wt} . \%$ ) and minimal tensile bending strength $6.5 \mathrm{MPa}[1]$.

This work is focused on the first step in the development of barium cement. The influence of barium ions on clinker phases was studied. By incorporation of barium ions into clinker minerals, the cement prepared from this clinker could shield different types of radiation.

Another reason to study the influence of barium on the formation and properties of Portland clinker is the use of alternative fuels and raw materials in manufacturing Portland cement. A small amount of barium leads to changes in the clinker. These alternative materials have gained more importance over the last decades and this trend continues. The use of these materials helps to save fossil fuels and natural raw materials but it contributes to the formation of the clinker phases and clinker properties can be changed. A thorough understanding of the influence of barium on clinker formation and properties is therefore crucial for an accurate evaluation of raw materials, fuels or process parameters [2].

Several authors have carried out research on clinkers with barium. Juel and Jones [3] prepared clinkers with different amounts of $\mathrm{BaO}$ and they detected barium mainly in the melt and belite. With increasing amount of $\mathrm{BaO}$, the dependence is linear. Katyal et al. [4] found no barium in $\mathrm{C}_{4} \mathrm{AF}$, while Juel and Jones considered the melt as a whole, i.e. they did not distinguish $\mathrm{C}_{3} \mathrm{~A}$ and $\mathrm{C}_{4} \mathrm{AF}$.

Substitution of $\mathrm{Ca}^{2+}$ ions for $\mathrm{Ba}^{2+}$ ions in belite causes a modification of the crystal. Udagava et al. [5] describe the composition of belite with barium as $\left(\mathrm{Ca}_{2-x} \mathrm{Ba}_{x}\right) \mathrm{SiO}_{4}$; they found $\beta-\mathrm{C}_{2} \mathrm{~S}$ when $x$ was between 0.03 and $0.05, \gamma-\mathrm{C}_{2} \mathrm{~S}$ if $x<0.03, \alpha^{\prime}-\mathrm{C}_{2} \mathrm{~S}$ if $x$ was between 0.05 and 0.10 and $\alpha-C_{2} S$ between 0.20 and 0.30 . The research was not carried out for $x$ higher than 0.30 .

Several authors $[4,6,7]$ focused on the miscibility limit of $\mathrm{BaO}$ in $\mathrm{C}_{3} \mathrm{~S}$. Kurdowski and Wollast [6] determined the limit at $1600^{\circ} \mathrm{C}$ as $1.5 \mathrm{~mol} . \%$ (i.e. $2.96 \mathrm{wt} . \%$ ). Appendino and Montorosi [7] found a compound with barium $\mathrm{Ca}_{1.86} \mathrm{Ba}_{0.14} \mathrm{SiO}_{4}$ formed at $1450^{\circ} \mathrm{C}$. By its composition they determined the miscibility limit as $1 \mathrm{~mol} . \%$ (1.99 wt. \%). Katyal et al. [4] prepared pure alite and its solid solutions with barium, the limit occurred at 1.85 wt. $\%$ of $\mathrm{BaO}$. Up to this amount, only a small percentage of free lime occurs - after recalculation to molar percentage, calcium ions were fully substituted in $\mathrm{C}_{3} \mathrm{~S}$ for barium ions. Above the miscibility limit barium led to decomposition of $\mathrm{C}_{3} \mathrm{~S}$ into $\mathrm{C}_{2} \mathrm{~S}$ and $\mathrm{CaO}$.

A high amount of $\mathrm{BaO}$ can negatively influence the presence of alite, while a small amount decreases viscosity and increases the amount of melt, prevents alite decomposition and increases the rate of alite formation $[4,8]$. 
In this work, barium oxide was added in the form of $\mathrm{BaCO}_{3}$ and $\mathrm{BaSO}_{4} \cdot \mathrm{CO}_{2}$ from the carbonate does not influence the clinker much because it is already present in the raw meal from calcite $\left(\mathrm{CaCO}_{3}\right) . \mathrm{BaSO}_{4}$ probably acts as a whole compound in the clinker because of its high decomposition temperature - around $1580^{\circ} \mathrm{C}$ [9]. Pure $\mathrm{BaCO}_{3}$ decomposes around $1098^{\circ} \mathrm{C}$ [10]. However, when burning of such heterogeneous material as raw meal, the decomposition temperatures can be only roughly estimated.

Some studies [11] were conducted to find out how $\mathrm{SO}_{3}$ affects the formation and properties of clinker phases, mainly alite. A high concentration of $\mathrm{SO}_{3}$ leads to lower viscosity and surface tension, dissolution of $\mathrm{CaO}$ is slow and due to low viscosity, the dissolved $\mathrm{CaO}$ is immediately transported and distributed in the sample. It takes more time for oversaturation of $\mathrm{CaO}$ which is needed for alite crystallization. When the crystallization starts, alite crystals grow fast to large sizes.

\section{EXPERIMENTAL}

The primary raw meal was prepared to obtain a clinker with $60-65 \mathrm{wt} . \%$ of alite and around $20 \mathrm{wt} . \%$ of clinker melt. As raw materials, limestone and highly pure chemicals were used including ground silica sand, $\mathrm{Al}(\mathrm{OH})_{3}$ and $\mathrm{Fe}_{2} \mathrm{O}_{3}$. Alkali compounds $\mathrm{Na}_{2} \mathrm{CO}_{3}$ and $\mathrm{K}_{2} \mathrm{CO}_{3}$ were added in amounts similar to industrial clinker.

The composition of the primary raw meal was verified by an equilibrium burning process which includes two burning steps. The first one has a heating rate of $10^{\circ} \mathrm{C} \cdot \mathrm{min}^{-1}$, isothermal dwell for two hours at $1100^{\circ} \mathrm{C}$ and fast cooling. The second one has the same heating rate up to $1450^{\circ} \mathrm{C}$ and isothermal dwell for four hours. This type of burning provides a homogenous structure of clinker due to complete reaction of $\mathrm{CaO}$ and separated crystallization of $\mathrm{C}_{3} \mathrm{~A}$ and $\mathrm{C}_{4} \mathrm{AF}$. The structure is then easier to recognize and appropriate for the microscopic point counting method. This method is based on counting of certain number of points (usually 2000) of a virtual grid placed on the surface of the clinker polished section. The section is etched by acetic acid vapour to obtain different interference colours of each phase $[12,13]$. The volume percentage of each phase is obtained and recalculated to weight percentage using the following densities for the individual phases (in $\mathrm{g} \cdot \mathrm{cm}^{-3}$ ): $\mathrm{C}_{3} \mathrm{~S}-3.15, \mathrm{C}_{2} \mathrm{~S}-3.28$, $\mathrm{C}_{3} \mathrm{~A}-3.03, \mathrm{C}_{4} \mathrm{AF}-3.77$ and free lime 3.35 .

The precision of this method is around $2 \%$ if the amount of the phase is high (around 70 vol. \%), around $7 \%$ if the amount of the phase is around 15 vol. $\%$ and around $20 \%$ for very low percentage of the phase (around 1 vol. \%).

Using the primary raw meal, 12 other raw meals were prepared with different amounts of barium oxide from zero to $5 \mathrm{wt}$ \% $\%$ and from different sources - barium carbonate and barium sulphate, see Table 1. All raw meals were burnt by an equilibrium burning process. Their structure and ratio of clinker phases were studied by petrographic polarizing microscopy (using Eclipse LV100ND by Nikon) and by X-ray diffraction (XRD, D8 Advance by Bruker) using Rietveld analysis (TOPAS V3 by Bruker).

Table 1. Samples with their amount and source of $\mathrm{BaO}$.

\begin{tabular}{ccc}
\hline Source of $\mathrm{BaO}$ & Sample & $\mathrm{BaO}$ (wt. \%) \\
\hline- & $\mathrm{S} 0$ & 0.0 \\
\hline $\mathrm{BaCO}_{3}:$ & $0.5 \mathrm{C}$ & 0.5 \\
& $1 \mathrm{C}$ & 1.0 \\
& $2 \mathrm{C}$ & 2.0 \\
& $3 \mathrm{C}$ & 3.0 \\
& $4 \mathrm{C}$ & 4.0 \\
& $5 \mathrm{C}$ & 5.0 \\
\hline $\mathrm{BaSO}_{4}:$ & $0.5 \mathrm{~S}$ & 0.5 \\
& $1 \mathrm{~S}$ & 1.0 \\
& $2 \mathrm{~S}$ & 2.0 \\
& $3 \mathrm{~S}$ & 3.0 \\
& $4 \mathrm{~S}$ & 4.0 \\
& $5 \mathrm{~S}$ & 5.0 \\
\hline
\end{tabular}

The rate of alite crystallization was analysed on small samples burnt in a laboratory furnace. Samples with a mass of around $54 \mathrm{mg}$ were burnt in isothermal conditions at $1430^{\circ} \mathrm{C}$ for $20 \mathrm{~s}, 30 \mathrm{~s}, 1,2,4,8,16$ and $30 \mathrm{~min}$. The structure of these burnt samples was observed and the beginning of alite formation was determined by petrographic polarizing microscopy.

The amount of $\mathrm{BaO}$ in clinker phases was evaluated in samples $\mathrm{S} 0,1 \mathrm{C}, 3 \mathrm{C}, 5 \mathrm{C}, 1 \mathrm{~S}, 3 \mathrm{~S}$ and $5 \mathrm{~S}$ by Scanning Electron Microscopy (SEM, using JSM 7600F by Jeol) with Energy Disperse Spectrometer (EDS, X-Max by Oxford Instruments) focussing on the presence of $\mathrm{BaO}$ in the main clinker phases - alite and belite.

\section{RESULTS AND DISCUSSION}

\section{Content of clinker phases}

The content of clinker phases was evaluated by the microscopic point counting method and verified by XRD Rietveld analysis. By the point counting method volume percentages of each phase were obtained and recalculated to weight percentages using the aforementioned densities. The contents are shown in Figure 1. At lower percentage of $\mathrm{BaO}, \mathrm{Ba}^{2+}$ ions probably substitute $\mathrm{Ca}^{2+}$ ions in clinker minerals and an appropriate molar percentage of $\mathrm{CaO}$ is produced as described in the literature [4]. With increasing amount of $\mathrm{BaO}$, the alite-belite ratio is decreasing in both cases. In the case of carbonate and sulphate as raw materials, the ratio is changed rapidly by additions higher than 2 - 3 wt. \% and 3 - 4 wt. \%, respectively. $\mathrm{BaO}$ obviously inhibits alite formation or causes alite decomposition to belite and free lime. In clinker 5C, there is already no alite present. 


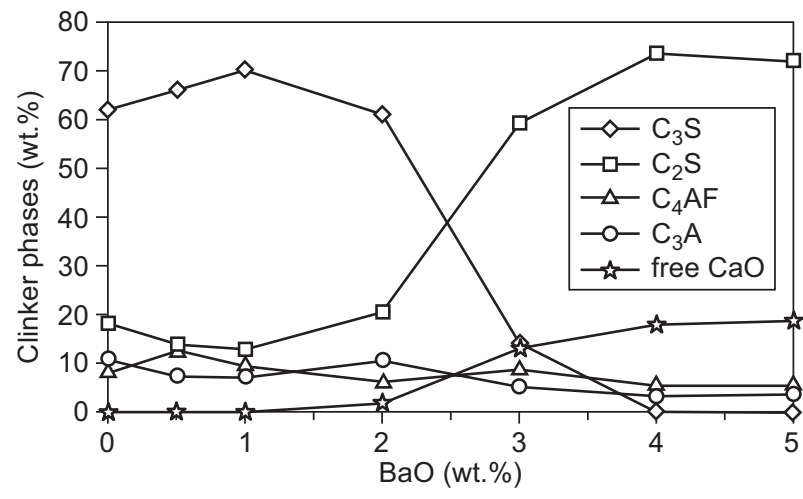

a) clinker with $\mathrm{BaCO}_{3}$

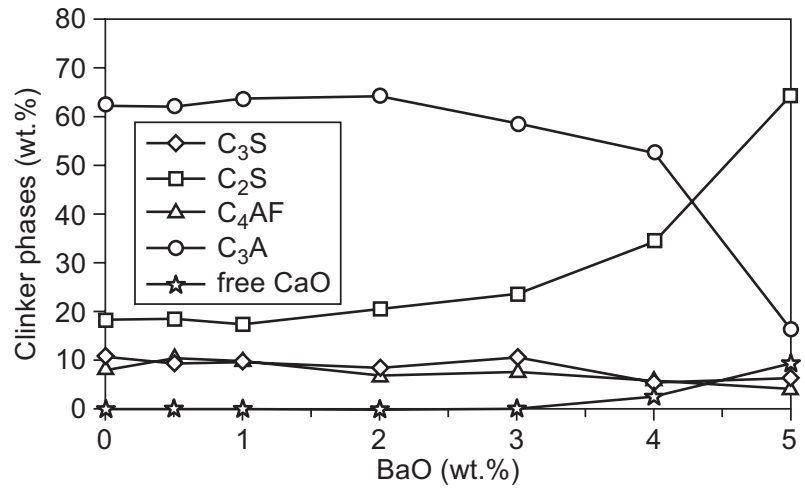

b) clinker with $\mathrm{BaSO}_{4}$

Figure 1. Phase composition of clinkers with $\mathrm{BaCO}_{3}$ (a) and $\mathrm{BaSO}_{4}$ (b) as measured by the microscopic point counting method.

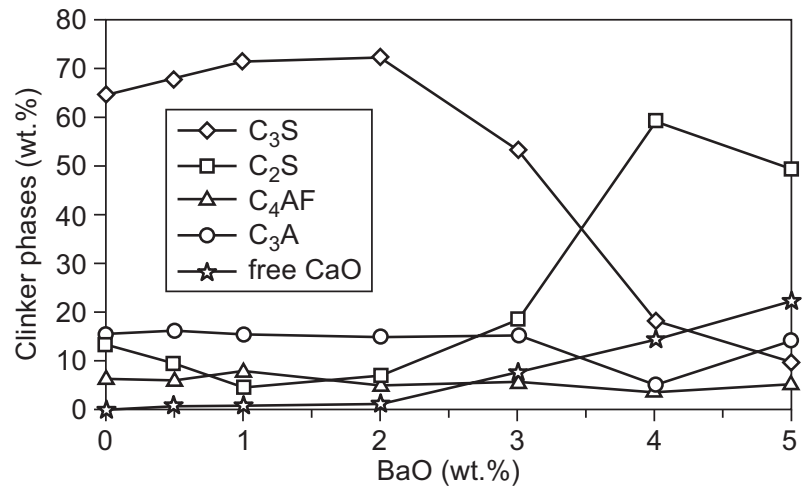

a) clinker with $\mathrm{BaCO}_{3}-\mathrm{XRD}$

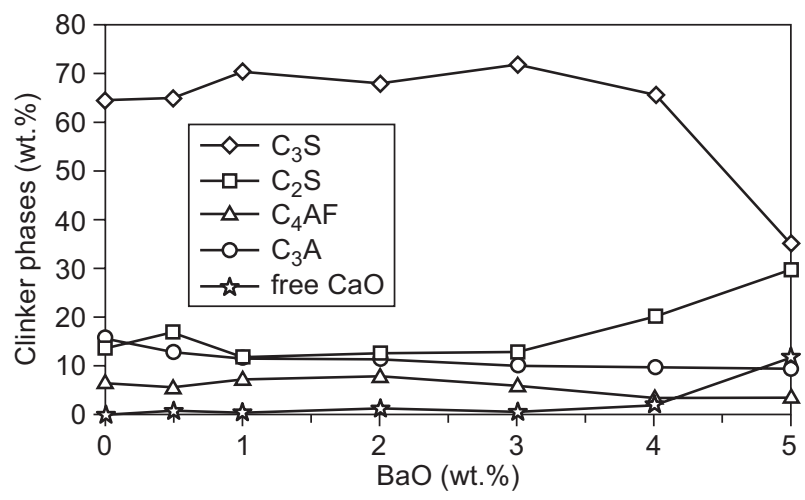

b) clinker with $\mathrm{BaSO}_{4}-\mathrm{XRD}$

Figure 2. Phase composition of clinkers with $\mathrm{BaCO}_{3}$ (a) and $\mathrm{BaSO}_{4}$ (b) as measured by XRD Rietveld analysis.

XRD Rietveld quantitative analysis (see Figure 2) showed that at low percentage of $\mathrm{BaO}$, the analysis gives very similar values as microscopic point counting. However, there are bigger differences between these two methods at higher percentage of $\mathrm{BaO}$. Higher percentage of $\mathrm{BaO}$ inhibits alite formation, but crystals of alite are formed on the surface of these clinkers which could not be separated for XRD analysis. Moreover, the incorporation of barium ions leads to deformation of the crystal structure, since barium ions are much bigger than calcium ions. In our experiments we were not able to determine and take into account the lattice distortion of the clinker phases. Therefore, Rietveld analysis probably does not give the best values in this case and the point counting results can be assumed to be more reliable. Diffractograms of some clinkers are shown in Figures 3 and 4.

By XRD qualitative analysis (see Figures 3 and 4) it was found that increasing the amount of $\mathrm{BaO}$ stabilizes the high temperature modification $\alpha^{\prime}-\mathrm{C}_{2} \mathrm{~S}$ in both cases, carbonate and sulphate. According to Udagava et al. [5] another belite modification should be stable $-\beta-\mathrm{C}_{2} \mathrm{~S}$ should be present when $x$ is between 0.03 and 0.05 in the compound $\left(\mathrm{Ca}_{1-x} \mathrm{Ba}_{x}\right) \mathrm{SiO}_{4}$, whereas $\alpha^{\prime}-\mathrm{C}_{2} \mathrm{~S}$ should be stable when $x$ is between 0.05 and 0.10 .
By observing samples via petrographic polarizing microscopy, other structural anomalies can be seen. Comparing clinkers with different amounts of $\mathrm{BaSO}_{4}$ (see Figure 5), the size of alite crystals is changing. Figure $5 \mathrm{~b}$ shows clinker with 5 wt. $\%$ of $\mathrm{BaO}$ with $\mathrm{BaSO}_{4}$, i.e. 2.6 wt. \% of $\mathrm{SO}_{3}$. Large crystals of alite can be seen. According to the literature [11], the presence of $\mathrm{SO}_{3}$ leads to lower viscosity and surface tension of the clinker melt during the burning process, calcium oxide dissolves quickly and is immediately transported away. Therefore, it takes longer time for oversaturation of calcium oxide which is necessary for alite crystallization. As soon as oversaturation occurs, crystallization is fast and the alite crystals attain large dimensions. The presence of both $\mathrm{SO}_{3}$ and $\mathrm{BaO}$ leads to a drop of the alite-belite ratio and an increase of the size of alite crystals.

\section{Rate of alite crystallization}

The rate of alite crystallization was measured after burning under isothermal conditions at $1430^{\circ} \mathrm{C}$ with different dwell times. In clinker without $\mathrm{BaO}$ or with a low content, alite starts to crystallize within less than $30 \mathrm{~s}$ at the interface between belite and $\mathrm{CaO}$ and continuously grows to areas with $\mathrm{CaO}$ and belite, see Figure 6a. 


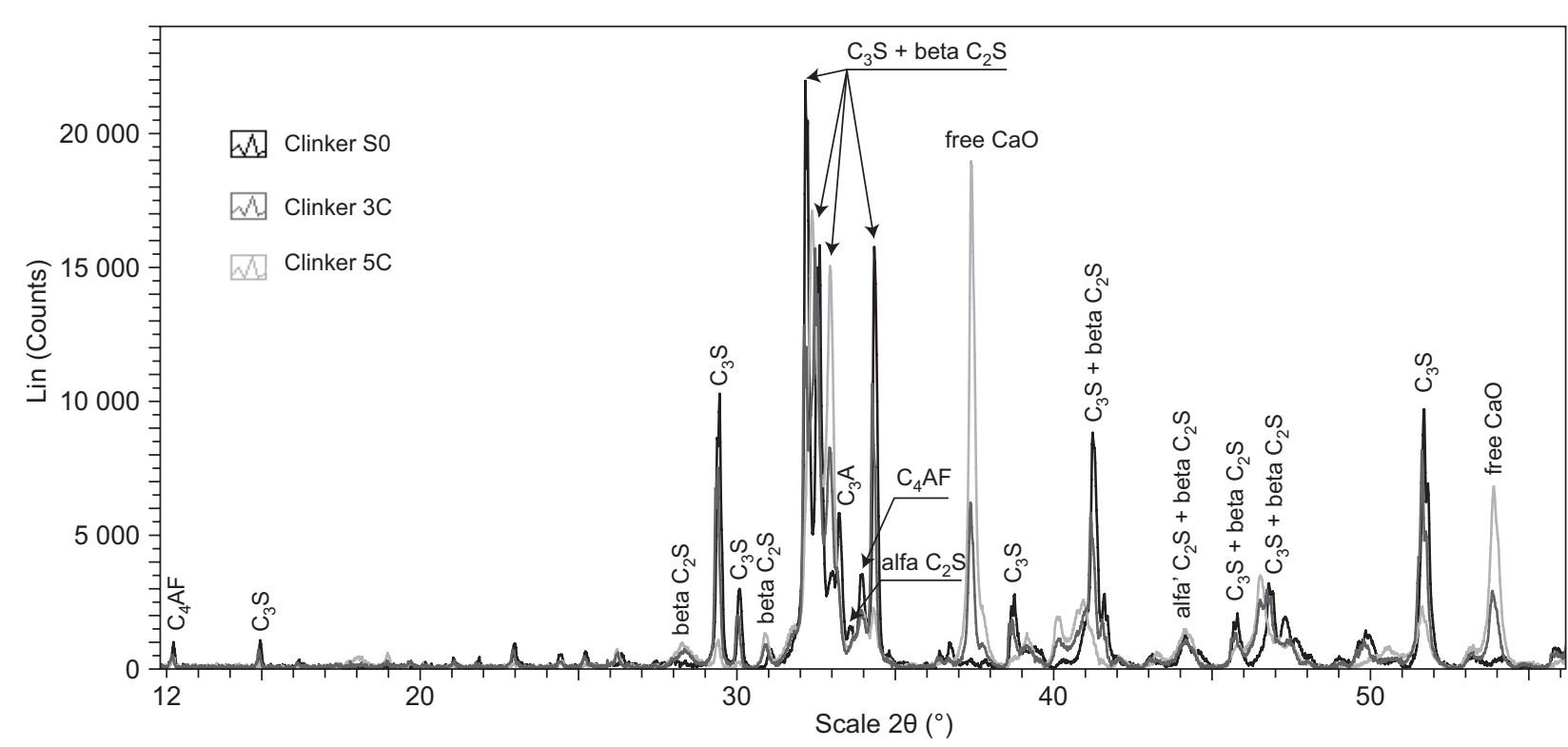

Figure 3. Diffractograms of clinker without $\mathrm{BaO}$ and with $\mathrm{BaCO}_{3}-3 \mathrm{C}$ and $5 \mathrm{C}$. The main peaks of each phase are displayed, but some peaks represent more phases.

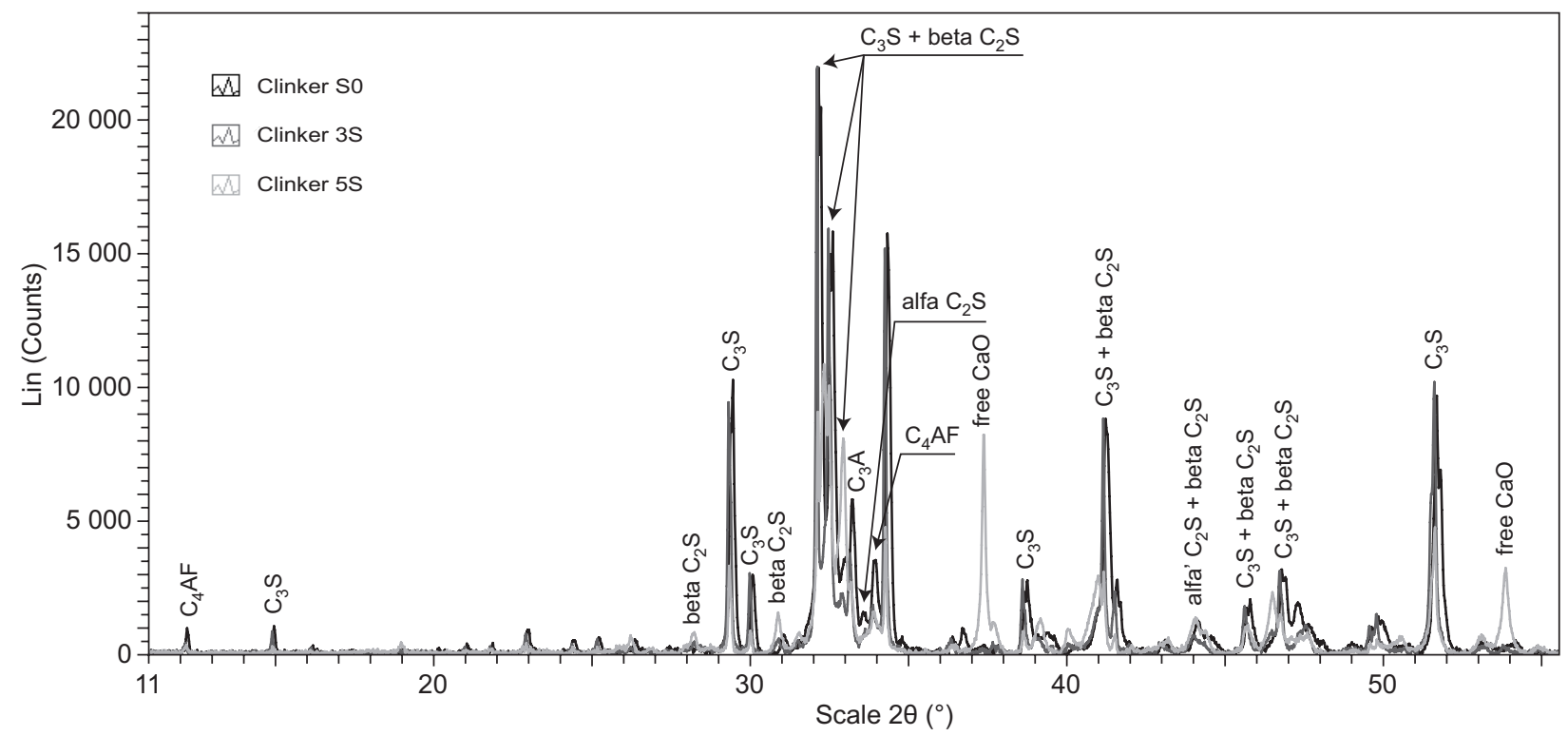

Figure 4. Diffractograms of clinker without $\mathrm{BaO}$ and with $\mathrm{BaSO}_{4}-3 \mathrm{~S}$ and $5 \mathrm{~S}$. The main peaks of each phase are displayed, but some peaks represent more phases.

Needle-shaped alite crystals are growing, while belite and $\mathrm{CaO}$ are becoming smaller and are finally trapped in alite crystals. After $30 \mathrm{~min}$, the crystallization is almost completed, with only a few grains of $\mathrm{CaO}$ remaining. The presence of a small amount of $\mathrm{BaCO}_{3}$ does not influence alite crystallization, but higher amounts of $\mathrm{BaCO}_{3}$ in the raw meal lead to a small delay in the crystallization of alite. Larger continuous areas of alite appear after around 4 minutes, and after 30 minutes the crystallization is completed.

Great changes occur in the case of sulphate as described in the literature [11]. Alite starts to crystallize later and the crystals are larger. Even small amounts of sulphate (sample 1S) lead to crystals twice as large as S0, crystallization starts after 1 minute. In clinker $5 \mathrm{~S}, \mathrm{CaO}$ is balanced with belite for a long time, alite starts to crystallize after 8 minutes but only at the surface of the sample, after 16 minutes inside the sample (see Figure 6b). After 30 minutes alite crystals attain large dimensions. Most of the crystals are at the surface where $\mathrm{SO}_{3}$ can easily become volatile.

\section{Presence of barium in clinker phases}

The amount of barium in different clinker phases was evaluated by SEM with EDS. The main focus was on alite and belite in the different samples (see Figure 7), clinker melt and free lime were measured only marginally. 


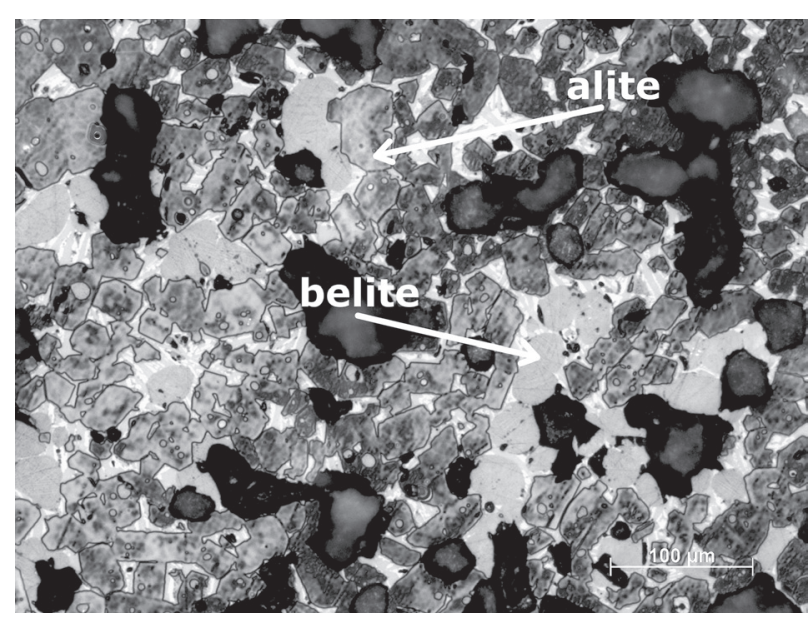

a) clinker $1 \mathrm{C}$

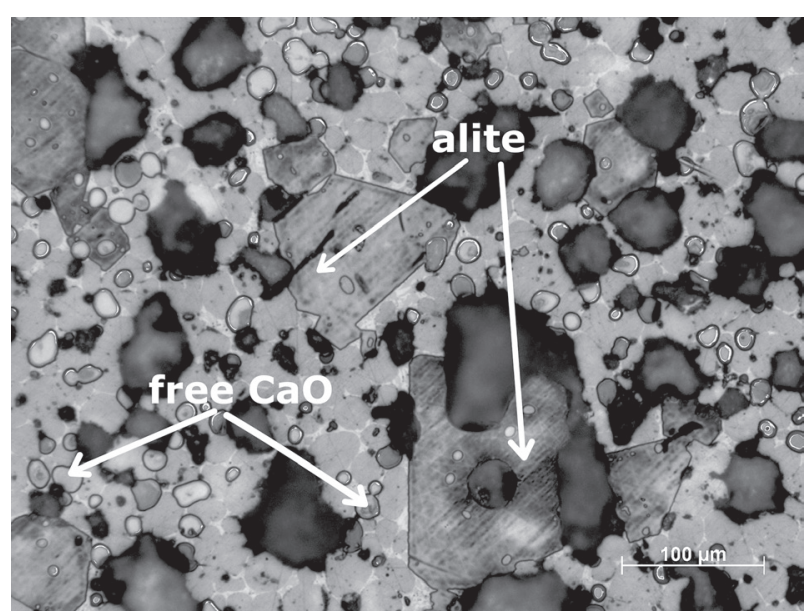

b) clinker $5 \mathrm{~S}$

Figure 5. Microstructure of clinker 1C (a): angular idiomorphic crystals - alite, light grey rounded grains - belite, light areas between grains - melt, large black areas - open pores; microstructure of clinker 5S (b): angular large crystals - alite, light rounded grains - belite, small rounded grains with visible boundaries - free lime, light areas between grains - melt, black large areas - open pores.

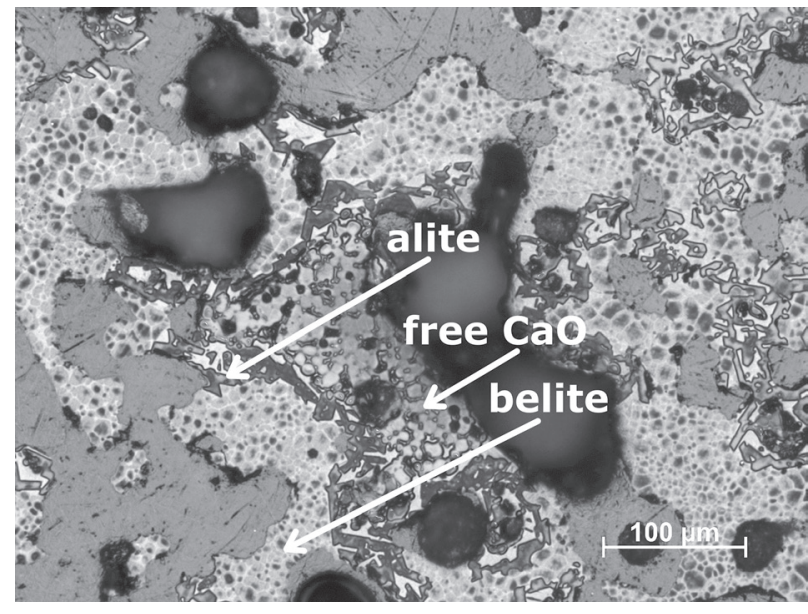

a) clinker $1 \mathrm{C}$

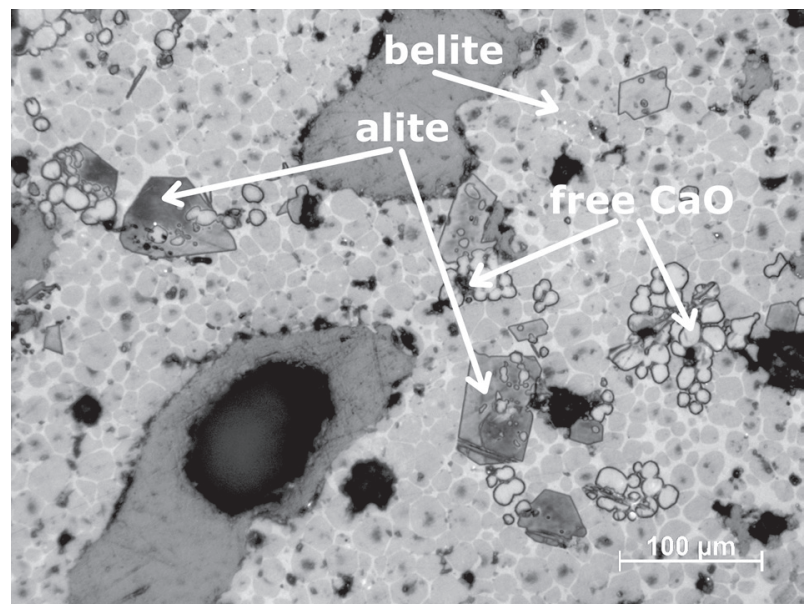

b) clinker $5 \mathrm{~S}$

Figure 6. Clinker 1C (a), burnt for $120 \mathrm{~s}$, needle-shaped grains - alite, small rounded grains inside alite needles - free lime, light small rounded grains - belite, light areas between grains - melt, large black areas - open pores, large grey area - epoxide; clinker 5S (b), burnt for $960 \mathrm{~s}$, large idiomorphic grains - alite, small rounded grains around alite crystals with visible boundaries - free lime, light small rounded grains - belite, light areas between grains - melt, black areas - open pores, large grey area - epoxide.

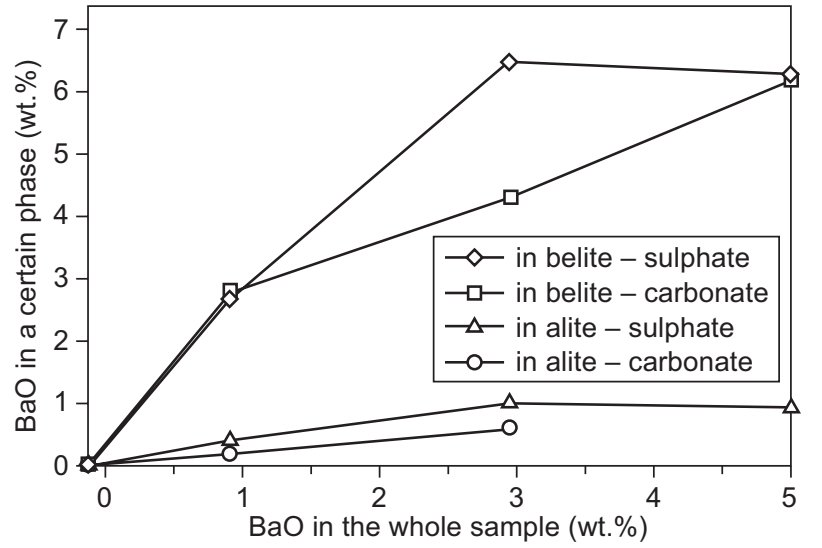

Figure 7. $\mathrm{BaO}$ in alite and belite evaluated by EDS.
It is not possible to exactly measure the amount of barium in clinker melt. Back scattered-electrons (BSE) do not probe only the sample surface, but involve also a non-negligible volume. In some cases, grains can be very close to each other, so the clinker melt, which fills the volume between grains, forms a thin layer and the background and surroundings of this melt cannot be neglected in measuring. Therefore, the amount of barium in the clinker melt can be only roughly estimated.

Clinker melt contains quite a high amount of barium. At higher percentage of $\mathrm{BaO}$ in the sample, aggregates of barium oxide are formed in clinker melt. Free lime does not contain any barium. Barium in alite and belite was measured in clinkers without $\mathrm{BaO}$ and with 1,3 and 5 wt. $\%$ of $\mathrm{BaO}$. As can be seen in Figure 7, belite 
incorporates much more barium than alite. The ratio of barium oxide in alite to barium oxide in belite remains almost the same - around 0.15 .

The difference between $\mathrm{BaO}$ in alite and belite is caused by differences in the crystal lattice of these phases. Evidently, alite cannot incorporate as much foreign ions as the crystal lattice of belite.

\section{CONCLUSION}

This paper deals with clinkers doped by barium oxide in the form of carbonate and sulphate. The influence of barium oxide on Portland clinker was studied. Different amounts and sources of barium oxide were used for the preparation of clinkers.

The content of clinker phases was evaluated by the microscopic point counting method and XRD Rietveld analyses. With increasing weight percentage of $\mathrm{BaO}$, the amount of alite decreases and belite with free lime increases. The presence of $\mathrm{BaO}$ probably leads to inhibition of alite formation or alite decomposition with formation of belite and free lime. This phenomenon is more significant when barium carbonate is used as a $\mathrm{BaO}$ source. When sulphate is used as a $\mathrm{BaO}$ source, the inhibition or decomposition of alite starts at a higher amount of $\mathrm{BaO}$.

By XRD it was found that increasing the amount of $\mathrm{BaO}$ stabilizes the high-temperature modification $\alpha^{\prime}-\mathrm{C}_{2} \mathrm{~S}$.

By measurement of the rate of alite crystallization under isothermal conditions, it could be shown that $\mathrm{BaCO}_{3}$ influences the start of alite crystallization only slightly, whereas significant changes occur for high amounts of $\mathrm{BaSO}_{4}$. The presence of $\mathrm{SO}_{3}$ causes lower viscosity and surface tension of clinker melt during the burning process. Calcium oxide can dissolve quickly, but longer time is needed for supersaturation of calcium oxide. Alite crystallization is then delayed, but when it starts, alite crystals grow fast to large dimensions. In case of sample $5 \mathrm{~S}$ ( 5 wt. $\%$ of $\mathrm{BaO}, 2.6$ wt. \% of $\mathrm{SO}_{3}$ ), alite crystallizes after around 16 minutes and the crystals are four times larger than without $\mathrm{BaO}$.

The presence of barium in certain clinker phases was observed by SEM with EDS. As was expected from data reported in the literature, belite and clinker melt contain more barium than alite and free lime. The ratio of barium in belite to barium in alite remains almost the same using different amount and source of $\mathrm{BaO}$. The great difference between alite and belite is probably caused by the different crystal lattices; alite can absorb less foreign ions than belite.

Generally, $\mathrm{BaO}$ has a considerable influence on clinker formation and properties. When using $\mathrm{BaSO}_{4}$, also $\mathrm{SO}_{3}$ leads to changes in alite crystallization. The optimal composition for barium clinker could be 2 - 3 wt. $\%$ of $\mathrm{BaO}$ when using $\mathrm{BaCO}_{3}$ and 3 - 4 wt. \% when using $\mathrm{BaSO}_{4}$. The amount of free lime is small, the ratio of clinker phases remains similar as in industrial clinker and of course the content of barium depends on the composition. After further analyses and tests, these clinkers could be probably used as binders or claddings for buildings resistant to radiation.

\section{Acknowledgements}

This paper was elaborated with institutional support for long-term development of research organizations by the Ministry of Industry and Trade of the Czech Republic.

The authors also thank the Ministry of Education, Youth and Sports of Czech Republic for the support of the project Sustainability and Development REG LO1211 addressed to the Materials Research Center at FCH VUT.

\section{REFERENCES}

1. Jirásek J., Vavro M. (2008). Nerostné suroviny a jejich využití. Ministerstvo školství, mládeže a tělovýchovy ČR \& Vysoká škola báňská - Technická univerzita Ostrava, 2008, 1 CD-ROM.

2. Böhm M., Lipus K. (2015). Evaluation of Portland cement clinker with optical microscopy - case studies III. In: Euroseminar on Microscopy Applied to Building Materials, 15, 33-37. Delft, The Netherlands.

3. Juel I., Jons E. (2001): The influence of earth alkalis on the mineralogy in a mineralized Portland cement clinker. Cement and Concrete Research. 31, 893-897. doi:10.1016/ S0008-8846(01)00512-9

4. Katyal N.K., Ahluwalia S.C., Parkash R. (1999): Effect of barium on the formation of tricalcium silicate. Cement and Concrete Research, 23, 1857-1862. doi:10.1016/S00088846(99)00172-6

5. Udagava S., Urabe K., Yano T. (1980): Stabilization mechanism and polymorphism of $\mathrm{Ca}_{2} \mathrm{SiO}_{4}$. in: Review of the $34^{\text {th }}$ General Meeting: Cement Association of Japan, Tokyo, Japan. pp.37-39.

6. Kurdowski W., Wollast R. (1970): Solid solution of BaO in tricalcium silicate. Silicates Industriels, 35, 153-159.

7. Appendino P., Montorsi M. (1971): The influence of Sr, $\mathrm{Ba}$, and $\mathrm{Mg}$ on the polymorphous transformations of tricalcium silicate. Il Cemento, 68, 89-98.

8. Chen L., Shen X., Ma S., Huang Y., Zhong B. (2009): Effect of barium oxide on the formation and coexistence of tricalcium silicate and calcium sulphoaluminate. Journal of Wuhan University of Technology-Mater, 24, issue 3, 457-461. doi:10.1007/s11595-009-3457-6

9. Vohlídal J., Julák A., Štuhlík K. (1999). Chemické a analytické tabulky. $1^{\text {st }}$ ed. Grada Publishing, a.s., Praha.

10.Carmona-Quiroga P.M., Blanco-Varela M.T. (2015): Use of barium carbonate to inhibit sulfate attack in cements. Cement and Concrete Research, 69, 96-104. doi:10.1016/j. cemconres.2014.12.006

11. Staněk T. (1993): Vliv $\mathrm{SO}_{3}$ a $\mathrm{MgO}$ na tvorbu portlandského slínku. Sbornik Cement, 93, 203-208.

12.ASTM C 1356 (2007). Standard Test Method for Quantitative Determination of Phases in Portland Cement Clinker by Microscopical Point-Count Procedure. American Society for Testing and Materials, West Conshohocken.

13. Chromý S. (1974): Anfärben des freien $\mathrm{CaO}$ und Silikate in Anschliffen von Portlandklinker. Zement-Kalk-Gips, 27, 79-84. 